\title{
SHARIA COMPLIANCE AND ISLAMIC CORPORATE GOVERNANCE
}

\author{
Aris Biyantoro \\ arisbiyantoro@std.unissula.ac.id \\ Nunung Ghoniyah \\ Faculty of Economics, Universitas Islam Sultan Agung Semarang \\ Jl. Kaligawe Raya, Semarang 50112, Indonesia
}

received: 18/3/19; revised: 17/7/19; published: 31/12/19

\begin{abstract}
This study aims to examine the effect of sharia compliance and Islamic corporate governance on fraud in Sharia banks. Independent variables used are sharia compliance with Profit Sharing Ratio as a proxy and Islamic corporate governance. The dependent variable used is fraud. The population in this study is all Sharia Banks which is registered in Bank Indonesia in the period 2015 to 2017. The sample was selected using purposive sampling method. Sample size in this research as much as 33 Sharia Banks. Those total samples used in this study which consist of 11 Sharia Banks within 3-year study period. The analytical method used in this study is multiple linier regression.The results of this study indicate that the sharia compliance with the Profit Sharing Ratio as a proxy, has a negative effect on fraud in Sharia bank while Islamic corporate governance has no positive effect on fraud in Sharia banks.
\end{abstract}

Keywords: sharia compliance; islamic corporate governance; fraud, sharia bank

\section{INTRODUCTION}

The success of Mit Ghamr Bank inspired many parties including the Organization of the Islamic Conference (OIC), which has members from various Muslim countries to establish the Islamic Development Bank (IDB) in 1973 (Yaya, 2014). The operation of the IDB triggered the establishment of Islamic banks throughout the world including in the European and Asian regions (Falikhatun dan Yasmin, 2012). In Southeast Asia, the development of Islamic banking took place in 1983 with the establishment of the Islamic Bank in Malaysia followed by the establishment of the first Islamic bank in Indonesia, namely Bank Muamalat Indonesia in 1992 (Yaya, 2014). The establishment of Bank Muamalat became the pioneer of the development of Islamic banking in Indonesia with the emergence of other Islamic banks (Sukardi, 2013). The development of Islamic banking in Indonesia is increasingly rapid after the enactment of Law Number 21 of 2008 concerning Islamic Banking (Falikhatun dan Yasmin, 2012). This development can be seen from the number of banks and the number of offices both in Sharia Commercial Bank (BUS), Sharia Business Unit (UUS), or the Islamic People's Financing Bank (BPRS).

But in reality, the element of sharia in an institution does not guarantee that the institution is free from fraud.
For example, the case of Bank Syariah Mandiri (BSM) implicates the internal bank, namely fictional lending to the BSM in Bogor for 102 billion rupiahs to 197 fictitious customers. As a result of the credit distribution, BSM has the potential to suffer losses of 59 billion rupiahs. For the case, the Indonesian National Police determined four suspects, those three of them were BSM employees (Prabowo, 2013). The other case is BRI Syariah and Bank Mega Syariah that were exposed to cases related to gold pawning. This case arises from the customers lawsuit of BRI Syariah and Bank Mega Syariah who feel disadvantaged due to gold pawning at BRI Syariah and Bank Mega Syariah (Djumena, 2014; Wijaya, 2012). Not only in Indonesia, several cases in Islamic banks have also occurred in other countries, as happened in the Dubai Islamic Bank which lost around US \$ 300 billion due to improper financial reports and in Islamic Bank of South Africa that went bankrupt in 1997 with debt around R50 to R70 million due to poor management and improper accounting and management systems (Rini, 2014). From the existence of these cases, it is proved that there is no guarantee that sharia institutions, especially sharia-based banks, are free from fraud. Every organization has the risk of fraud in all its forms and modes.

Therefore, a pillar is needed to guarantee the application of sharia principles in banking institutions, 
namely shari' ah compliance and the application of the principles of Islamic Corporate Governance which are aimed at public accountability related to bank operations that are expected to truly comply with the provisions outlined in the positive law. In addition, it also relates to the compliance of Islamic banks in sharia principles as outlined in the Qur'an, Hadiths, and Ijma' of the scholars (Maradita, 2014). (Asrori, 2011) found empirical evidence in the disclosure practice of sharia compliance in Islamic banks financial report in Indonesia is still low. It was alleged that the trustworthiness of accountants and managers of Islamic banks towards the use of sharia compliance disclosure practices as responsibility for compliance with Islamic banks towards sharia principles was still low. This result is supported by (Junusi, 2012) which states that the low compliance with sharia principles provides an opportunity for fraud to occur in Islamic banks. Therefore, guarantees regarding the fulfillment of shariah compliance from all activities of managing customer funds by Islamic banks are very important in the business activities of Islamic banks. There are not many studies that examine the effect of sharia compliance on fraud.

Previous research on sharia compliance was dominated by examining sharia compliance and the performance or health level of Sharia Banks. As research conducted by (Hameed et al., 2004) regarding the disclosure and measurement of the Islamic banks performance, the study compared Bahrain Islamic Bank and Bank Islam Malaysia Berhad using the Islamic Disclosure Index (IDI). Sharia principles assessment index of Hameed consists of three factors, namely indicators of sharia compliance, corporate governance, and social. The results of the study indicate that the performance of Bahrain Islamic Bank (BIB) is better than Bank Islam Malysia Berhad (BIMB).

According to (Asrori, 2011), regarding the attitudes and interests of Islamic bank accountants and managers towards the practice of sharia compliance, it shows the results that there are positive relationship between accountants and managers of Islamic banks on the shariah compliance practice disclosure. The same research was done by (Falikhatun dan Yasmin, 2012) who tested the effect of sharia compliance on the financial health of Islamic banks with the result showed that Islamic compliance had a significant effect on the financial health of Islamic banks. If Islamic banks are in a healthy condition, the culture of fraud can be minimized. This finding is supported by (Najib \& Rini, 2016), it is stated that sharia compliance has a negative effect on the culture of fraud.

The Sharia Banks operation is inseparable from the demands of the implementation of good corporate governance and based on Islamic principles which are referred to as Islamic corporate governance. The demands of this governance were caused by the crisis in the banking sector which was generally dominated by conventional banking in 1997 which continued until 2000. The banking crisis that hit Indonesia was not as a result of the decline in the rupiah exchange rate, but due to the lack of good corporate governance practices among banks. The violation of the maximum credit limits, the low-risk management practices, the absence of transparency on financial information to customers, and the dominance of shareholders in managing banking operations led to the collapse of the national banking industry (Maradita, 2014). The good implementation of corporate governance and has a value added based on Islamic principles, gives an indication and impression to the public that sharia institutions, especially banks, are protected from fraudulent practices, although fraud can occur anywhere.

Several previous studies that examined corporate governance in Islamic banks, as conducted by (Asrori, 2014) which examined the implementation of Islamic corporate governance and its implications for the Islamic banks performance, it showed that Islamic corporate governance affects Islamic banks performance. (Anugerah, 2014) also shows the results that implementing internal and external Corporate Governance mechanisms by paying attention and carrying out all principles and functions can reduce the occurrence of fraud. Based on theory and previous research on Islamic corporate governance and its effect on fraud as described above, it can be seen that the better implementation of corporate governance, it is expected that fewer frauds will occur in Islamic banks. Whether good or not the implementation of governance in Islamic banks, it can be seen from the existence of the Sharia Supervisory Board (BI Circular No.12 / 13 / DPbS concerning the implementation of GCG for Sharia Commercial Banks and Sharia Business Units). The more the members of the DPS, the more compliant the bank will be on sharia principles in making all transactions. On the other hand, Islamic banks that pay less attention to sharia principles will become one of the things that can affect the reputation and trust of the people in Islamic banks. This will also have an impact on the loyalty of the people using Islamic banking services (Junusi, 2012).

\section{METHODS}

The population in this study was all Sharia Bank registered at Bank Indonesia in 2015-2017. The banks were chosen as the object of research because the research conducted by the (Association of Certified Fraud Examiners (ACFE), 2012) showed that banks became one of the most victims of fraud in industries and had their own principle in conducting their activities. The selection of samples in this study used a purposive sampling method, with criteria: (1) Sharia banks that publish annual financial reports in 2015-2017 and are 
expressed in rupiah; (2) Sharia banks that publish reports on the implementation of Islamic Corporate Governance in 2015-2017; and (3) Sharia Banks that disclose data relating to research variables completely, including fraud, sharia compliance which are proxied by the Profit Sharing Ratio, and Islamic Corporate Governance.

Fraud is an intentional illegal act, marked by deception, concealment or breach of trust carried out by tricking, deceiving or manipulating to gain profit (Hall, 2011). Fraud variable is measured by looking at the number of internal frauds that occur in Islamic banks which are disclosed in the annual report on GCG implementation in each Islamic bank. Internal fraud is used because study focuses on fraud that occurs in occupational fraud or which is also called as internal fraud. Sharia compliance is an implementation of Islamic principles measured by the level of compliance of Islamic banks towards the implementation of sharia principles in the activities of collecting and channeling Islamic bank funds using the proxy of Profit Sharing Ratio (PSR) (Hameed, et al., 2004). The Profit Sharing Ratio is used to see how sharia banks use profit-sharing in their activities with total financing. This ratio compares the amount of financing with the principle of profit sharing with the financing provided as a whole. A ratio for calculating profit sharing from financing carried out by sharia banks including Mudharabah and Musyarakah. Islamic Corporate Governance is a corporate governance based on Islamic principles as measured by the existence of a Sharia Supervisory Board (Bank Indonesia, 2010).

This study uses secondary data, namely data in the form of financial reports and reports on the implementation of the annual Islamic Corporate Governance in the period of 2015-2017 which will then be processed using multiple linear regression (Ghozali, 2013), as follows:

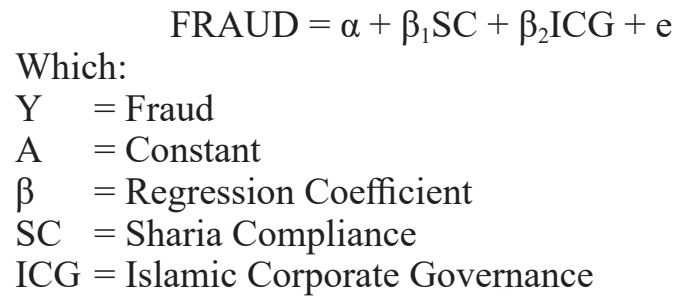

\section{RESULT}

The normality test aims to test whether in the regression method, the residual confounding variable has a normal distribution (Ghozali, 2016). One method used to see normality is the Kolmogorov-Smirnov test. The test results for detecting normality can be seen in Table 1 . The calculation results show K-S value of 0.366 and not significant at 0.05 . The value of $p=0.899>$ than 0.05 , then the residual data is normally distributed.

The multicollinearity test aims to test whether the regression model is found to have a correlation between independent variables (Ghozali, 2016). This test can be done by looking for the VIF value and tolerance value. Based on the 3 coefficient table in the regression output, it can be seen that the tolerance value and VIF for each variable are in Table 2.

The results of the above calculation show that there are no independent variables which has a tolerance value of less than $10 \%$, which means that there is no correlation between independent variables whose value is more than $95 \%$. The calculation results of VIF values also show the same thing that there are no independent variables which has a VIF value of more than 10. So it can be concluded that there is no multicollinearity between independent variables in the regression model.

Durbin-Watson value is 2,324, which means that the $\mathrm{d}$ value is between $\mathrm{dL}$ and $\mathrm{dU}$ or between (4-du) and (4$\mathrm{dL}$ ) which is 2,021 2,02,324 92,985; then the DurbinWatson test does not produce definite conclusions (inconclusive). The auto-correlation test results with durbin-watson appear in Table 3.

To test for heterocedasticity the Glejser test uses the Residual Absolute (AbsUt) value as the dependent variable. This test expects that all tested variables are not significant or the probability of significance is greater than $5 \%$. The results of heteroscedasticity testing with the glejzer test are shown in Table 4.

Based on the table above, all tested variables are not significant or the probability of significance is greater than $5 \%$, so it can be concluded that the regression model does not contain any heterocedasticity.

Regression analysis for the first model shows a good "goodness of fit model" because the Anova test produces a value of $\mathrm{F}=5.451$ and $\mathrm{p}$-value of 0.002 (less than 5\%). The coefficient of determination for this model is shown by adjusted $\mathrm{R}^{2}$ of 0.31201 . This means that 31.20 percent of data variation in fraud can be explained by data variations from sharia compliance and Islamic corporate governance; while the remaining 68.8 percent explained variations from other variables outside the model.

\section{DISCUSSION}

Sharia compliance that is proxied by Profit Sharing Ratio has a negative effect on fraud. It can be interpreted that when the value of Profit Sharing Ratio is high, the amount of fraud that occurs is low. The higher Profit Sharing Rate indicates that the more transactions with the principle of the results carried out by Islamic banks, it can negatively affect fraud because the principle of profit sharing is one of the principles in the operation of Islamic banks which is basically a differentiator between Islamic banks and conventional banks. The principle of profit sharing in Islamic banks is also expected to drive the real sector 
more because it closes the possibility of disbursing funds to consumptive interests. In addition, when viewed from the principle of compliance with sharia, the principle of buying and selling and leasing (the principle of financing other than profit sharing) creates a greater gap to deviate from sharia principles (Donna, 2012), and is considered to reflect the characteristics of Islamic banks (Pramono, 2013). So that when the principle of profit sharing is dominant in Islamic banks, the gap for fraud is getting smaller, thus the condition of Islamic banks will be better. This is consistent with research of (Falikhatun dan Yasmin, 2012), it is concluded that the implementation of sharia principles has a positive effect on the financial health of Islamic banks, and research of (Maharani, 2013) stated that the Islamic element applied in business ethics has a significant negative effect on fraud in financial report.

The implementation of corporate governance is a must for an institution including sharia bank, this is more aimed at the existence of public responsibility related to the operational activities of banks that are expected to comply with the provisions outlined (Maradita, 2014). However, in its implementation, it is very difficult to implement corporate governance optimally, especially for Islamic banks that use sharia or Islamic laws as a principle, where Islamic banks in Indonesia are still relatively new and are still in the stages of adjustment and development so that it cannot be said to have implemented principle.

The statement above is in accordance with the research results of IRTI (Islamic Research \& Training Institute) in (Wardayati, 2011) which shows that GCG has not been well implemented in Islamic banking in various countries. In addition, the lack of understanding of HR (Human Resources) on Islamic banks towards the mechanism and principles of sharia has caused the maximum implementation of Islamic values that exist in Islamic banks resulting in a public impression that the practice of Islamic banking is not conventionally different (Rahmanti, 2013). Therefore, the Islamic corporate governance in Islamic banks has not been effective in influencing fraud, so it needs to be carried out continuously for the implementation of corporate governance in accordance with Islamic principles and effective to implement. This study supports the research conducted by (In'airat, 2015) which states that the existence and application of corporate governance is not enough to reduce the level of fraud, as well as research of (Rahmanti, 2013) which states that one of the triggers for the development of Islamic banks and why Islamic banks are still identified with conventional banking is due to lack of HR understanding in Islamic banking towards the nature of sharia. However, the results of this study conflict with the research conducted by (Anugerah, 2014) which states that corporate governance can reduce the level of fraud.

\section{CONCLUSION}

The results of multiple linear regression tests conducted in this study show that sharia compliance proxied by profit sharing ratio has a negative effect on fraud in sharia banks while the Islamic corporate governance variable has no a positive effect on fraud at sharia commercial banks. The limitations of this research are: firstly, the dependent variable in this model can only explain $31.2 \%$ of the variable variation of fraud on Islamic banks; secondly, the sample that used in this research focus only to sharia banks, and the last one is proxy that used for sharia compliance is only focus on a profit sharing ratio. The suggestions for further researches are: need to add more variables such as internal audit, internal control, and external audit. Besides that, they need also to expand the population by adding other types of Islamic financial institutions such as Sharia Unit, BPRS or Sharia Insurance, and using other proxies that are different in measuring sharia compliance and Islamic corporate governance variables. Finnaly, the results of this study can provide new insights and knowledge to the academic community in general and master management students in particular and become a reference for future research.

\section{REFERENCES}

Anugerah, R. 2014. Peranan Good Corporate Governance Dalam Pencegahan Fraud. Jurnal Akuntansi, 3(1), 101-113.

Asrori. 2011. Pengungkapan Syari'ah Compliance dan Kepatuhan Bank Syariah Terhadap Prinsip Syariah. Jurnal Dinamika Akuntansi, 3(1), 1-7. https://doi.org/10.1016/S0140-6736(88)92185-X

Asrori. 2014. Implementasi Islamic Corporate Governance dan Implikasinya Terhadap Kinerja Bank Syariah. Jurnal Dinamika Akuntansi, 6(1), pp.90-102. https://doi.org/ISSN: 2085-4277

Association of Certified Fraud Examiners (ACFE). 2012. Report to the Nation on Occupational Fraud and Abuse.

Bank Indonesia. 2010. Surat Edaran Bank Indonesia Nomor 12/13/DPbS Tahun 2010 Tentang Pelaksanaan Good Corporate Governance bagi Bank Umum Syariah dan Unit Usaha Syariah., 5.

Djumena, E. 2014. Bank Mega Syariah Terseret Kasus Investasi Emas?.

Donna, D. R. 2012. Analisis Faktor-Faktor yang Berpengaruh terhadap Penggunaan Lembaga Bank Syariah: Studi di Propinsi Daerah Istimewa Yogyakarta. Kawistara, 2(3).

Falikhatun, F. and Assegaf, Y.U., 2012. Bank Syariah Di Indonesia: Ketaatan Pada Prinsip-Prinsip Syariah Dan Kesehatan Finansial. In 1st Conference in Business, Accounting, and Management 2012. Sultan Agung Islamic University. 
Ghozali, I. 2013. Analisis Multivariate dengan Program SPSS. Fakultas Ekonomi Universitas Diponegoro.

Hall, J. A. 2011. Accounting information systems (7th ed.). Mason, USA: Cengange Learning. Hamdani.

Hameed, S. et al. 2004. Alternative Disclosure and Performance Measures for Islamic Banks. International Islamic University Malaysia.

In'airat, M. 2015. The Role of Corporate Governance in Fraud Reduction - A Perception Study in the Saudi Arabia Business Environment. Journal of Accounting and Finance, 15(2), 119-128.

Junusi, R. 2012. Implementasi Syariah Governance serta Implikasinya terhadap Reputasi dan Kepercayaan Bank Syariah. Al-Tahrir, 12(1), 91-115.

Maharani, S. 2013. Pengaruh Etika Bisnis Islam terhadap Kecenderungan Kecurangan Akuntansi dalam Pelaporan Keuangan pada Entitas Publik di Indonesia. IJTIHAD, 7(2).

Maradita, A. 2014. Karakteristik Good Corporate Governance. Yuridika, 29(2), 191-204.

Najib, H., \& Rini. 2016. Sharia compliance, islamic corporate Governance dan fraud pada bank syariah. Sharia Comliance, 4(2), 131-146.

Prabowo, D. 2013. Kredit Fiktif BSM Terendus Sejak 2012, 3 Pegawai Sudah Dipecat.

Pramono, N. H. 2013. Optimalisasi Pembiayaan

Table 1. One-Sample Kolmogorov-Smirnov Test

\begin{tabular}{llc}
\hline & & $\begin{array}{c}\text { Unstandardized } \\
\text { Predicted Value }\end{array}$ \\
\hline $\mathrm{N}$ & & 33 \\
Normal Parameters $^{\mathrm{a}}$ & Mean & -.075324 \\
& Std. Deviation & .0339145 \\
Most Extreme Differences & Absolute & .066 \\
& Positive & .058 \\
& Negative & -.063 \\
Kolmogorov-Smirnov Z & & .366 \\
Asymp. Sig. (2-tailed) & & .899 \\
\hline Source: Data processed
\end{tabular}

Source: Data processed, 2019

Table 2. Multicollinearity Test Results

\begin{tabular}{lcc}
\hline \multicolumn{1}{c}{ Variable } & Tolerance & VIF \\
\hline Sharia Compliance & .895 & 1.012 \\
Islamic Corporate Governance & .898 & 1.015 \\
Fraud & .899 & 1.011 \\
\hline
\end{tabular}

Source: Data processed, 2019
Berbasis Bagi Hasil pada Bank Syariah di Indonesia. Accounting Analysis Journal, 2(2).

Rahmanti, V. N. 2013. Mengapa Perbankan Syariah Masih Disamakan dengan Perbankan Konvensional? Jurnal Ekonomi, Manajemen Dan Akuntansi Islam, 1(1).

Rini, R., 2014. The effect of audit committee role and sharia supervisory board role on financial reporting quality at Islamic banks in Indonesia. Journal of Economics, Business \& Accountancy Ventura (JEBAV), 17(1), pp.145-156.

Sukardi, B. 2013. Corporate Governance Engineering of Islamic Banking and Finance: Tantangan Globalisasi Sistem Ekonomi dan Pasar Bebas. Jurnal TSAQAFAH, 9(1).

Wardayati, S. M. 2011. Implikasi Shariah Governance terhadap Reputasi dan Kepercayaan Bank Syariah. Walisongo, 19(1).

Wijaya, A.S., 2012. Kasus Gadai Emas Perburuk Citra Produk Syariah. Melalui https://m. tempo. co/read/ news/2012/10/04/087433724/kasus gadai-emasperburuk-citra-produk-syariah. Diakses pada, 5.

Yaya, R., Martawireja, A.E. and Abdurahim, A., 2014. Akuntansi Perbankan Syariah: Teori dan Praktik Kontemporer berdasarkan PAPSI 2013 edisi 2. Salemba Empat.

Table 3. Autocorrelation Test Results

\begin{tabular}{ccccc}
\hline $\mathrm{N}$ & $\mathrm{K}$ & $\mathrm{DW}$ & $\mathrm{Du}$ & $\mathrm{Dl}$ \\
\hline 33 & 3 & 2,324 & 1,435 & 1,070 \\
\hline
\end{tabular}

Source: Data processed, 2019

Table 4. Heterocedasticity Test Results

Coefficients $^{\mathrm{a}}$

\begin{tabular}{|c|c|c|c|c|c|c|}
\hline \multirow[b]{2}{*}{ Mode } & & \multicolumn{2}{|c|}{$\begin{array}{c}\text { Unstandardized } \\
\text { Coefficients }\end{array}$} & \multirow{2}{*}{$\begin{array}{c}\begin{array}{c}\text { Standardized } \\
\text { Coefficients }\end{array} \\
\text { Beta }\end{array}$} & \multirow[b]{2}{*}{$\mathrm{t}$} & \multirow[b]{2}{*}{ Sig. } \\
\hline & & B & Std. Error & & & \\
\hline \multirow[t]{4}{*}{1} & Constant & .336 & .310 & & 1.439 & .162 \\
\hline & $\mathrm{SC}$ & -.062 & .125 & -.088 & -.468 & .658 \\
\hline & ICG & .017 & .118 & .013 & .065 & .994 \\
\hline & Fraud & .024 & .056 & .118 & .520 & .808 \\
\hline
\end{tabular}

a. Dependent Variable: Absut

Source: Data processed, 2019 